\title{
THE IMPACT OF THE INFLOW OF FOREIGN DIRECT INVESTMENTS ON THE ECONOMIC DEVELOPMENT OF SERBIA
}

\author{
Slaviša Kovačević', Mladen Rebić ${ }^{2}$, Drago Kurušić ${ }^{3}$
}

Received 17. 06. 2021.

Sent to review 20. 06. 2021.
Accepted 04. 09. 2021.

\section{Original Article}

\author{
${ }^{1}$ University Banja Luka, Faculty of \\ Economics, Bosnia and Herzegovina, \\ ${ }^{2}$ University of East Sarajevo, Faculty of \\ Economics, Bosnia and Herzegovina, \\ ${ }^{3}$ BitLab d.o.o, Bosnia and Herzegovina,
}

\section{Corresponding Author: \\ Mladen Rebić \\ Email: rebicmladen@yahoo.co.uk}

JEL Classification:

E22, E24

Doi: 10.2478/eoik-2021-0022

UDC: $339.727 .22(497.11): 330.101 .541$

\begin{abstract}
Foreign direct investments present one of the very important products of globalization, by establishing a new economic concept of free international movement of capital, people, goods and services. An analyses of the impact of this type of international movement of capital on economic growth and development is one of the modern tendencies of economic researchers. The subject of this paper is the analysis of the impact of the level and structure of foreign direct investment on the economic development of the Serbian economy, where the impact of foreign direct investment inflow on economic growth, current balance, manufacturing industry through the impact on total industry turnover, employment and productivity will be separately considered. The aim of this research is to prove the importance of FDI for developing countries, as well as to point out the need to improve and enhance the business environment in order to maximize FDI inflows. The main hypothesis of this research is that foreign direct investments significantly contribute to the economic growth and development of the Republic of Serbia. For the purposes of hypothesis analysis and testing, a simple linear regression model was used in this paper. The research was conducted for the period from 2010 to 2019. The obtained results present a positive relationship between the inflow of foreign direct investment and GDP growth, and show a positive relationship between growth of investments in manufacturing and growth in productivity, employment and total turnover, and show a positive relationship between FDI inflow and export value.
\end{abstract}

Keywords: globalization, economic growth, economic development, foreign direct investment, international capital movements.

\section{INTRODUCTION}

The globalization of the world economy has significantly facilitated the movement of capital across borders, which has enabled the intensification of investment at the global level. Foreign direct investment is a very important source of investment in less developed countries and is one of the most important factors leading to economic growth in countries. Due to the insufficient level of savings in the developing countries, the foreign investments in the domestic economy are the important holder of economic growth of these countries. One of those countries is Serbia, which bases its economic policy on the largest possible volume of attracting foreign direct investments. FDI represents real investments in production factors: in capital goods, in land or stocks where the investor is involved in both investment and management, while maintaining control over the use of invested capital. This type of investments holders in the world are mainly multinational companies (TNCs) in the field of processing industry, exploitation of raw materials or from the field of services (Salvatore, 2009). There are two basic types of foreign direct investments; they are Greenfield and 
Brownfield investments. Greenfield investments represent the construction of completely new capacities in the host country. It is the investor who buys the land, builds the production plant in the host country, and starts production. In this way, the foreign company increases the existing plants, or directly invests in the new plants and equipment in the area where there were no such plants. This type of investment is the primary goal of the host country because it increases production and business capacities, creates new jobs, transfers technology and knowledge, and includes the country in the global market as well. However, it should be kept in mind that these investments can bring certain problems to the host country, and which are related to the suppression of local industry by cheaper production thanks to more superior technology and efficiency of business management and utilization of land resources such as labor, goods and raw materials. Also, there is the question of the purpose of the realized profit, which in most cases leaves the country, unlike domestic investors who use it in the development of the domestic economy is a question of the purpose of the realized profit, which in most cases leaves the country, unlike domestic investors who use it in the development of the domestic economy. "Brownfield investments are hybrid model that combines acquisition and Greenfield investment. Formally, these are acquisitions, but essentially they are more like Greenfield investments, because the investor almost completely replaces the production facilities, equipment and production line" (Mikerević, 2011).

In the corresponding literature the importance of technological change for economic growth, and role of FDI in that process, has been widely emphasized (Hayat, 2019; Grossman \& Helpman, 1991, Dunning, 1993; Porter, 1990; Vernon, 1966). These include employment creation (and associated rising incomes), technology transfer and general upgrading of industrial standards to world levels (Akbar \& McBride, 2004). “There is a widely shared view that FDI accelerates host countries' growth by (1) augmenting domestic savings and investment, (2) helping transfer of technology from the "leaders," (3) increasing competition in the host country's domestic market, (4) increasing exports and earning foreign exchange, and (5) imparting several other types of positive externalities (spillovers) to the economy atlarge" (Ram \& Zhang, 2002, p. 205). But in other hand, we also find empirical studies with confronting results regarding to importance of FDI to economic growth. For example, Bruno and Campos (2013) in their study of 1102 estimates found that about $44 \%$ of the research papers discover a positive and significant impact of FDI on growth, $44 \%$ were insignificant, while $12 \%$ have a negative and significant effect of FDI on the host country's economic growth.

Developing countries have major problems in accelerating technological development. One of the basic modalities for accelerating the growth rate of developing countries is FDI, which enables the availability and adaptation of new technologies (technological diffusion), all with the aim of reaching the technologies and knowledge of highly developed countries in the world(Hermes \& Lensink, 2003). The speed of adoption of new technologies by domicile countries, according to empirical studies, depends on several factors (Hayat, 2019). These factors are related to the absorptive capacity of the host country, and the most important are: level of economic development (Blomstrom, Lipsey, \& Zejan, 1994), financial markets development (Alfaro et al., 2004; AzmanSaini, Siong, \& Ahmad, 2010); human capital (Borensztein, De Gregorio, \& Lee, 1998) economic stability and liberal markets (Bengoa \& Sanchez-Robles, 2003), technology gap between the host and origin country (Havranek \& Irsova, 2011), etc.

Many countries like Serbia, have based their development strategies on attracting foreign capital in the form of investments. The official policy of the Serbian government, from 2000 until today, has based its economic program on attracting foreign investments, in order to achieve economic growth and increase the standard of living of Serbian citizens. This economic policy has become especially important since 2012, when the policy of providing subsidies to foreign investors per employee and capital employed to all interested foreign investors who have capital has intensified. The aim of this paper is the analysis of the impact of foreign direct investments on the economic growth and development of Serbia. We will also analyze the impact of foreign direct investments in the Serbian economy, especially in the manufacturing industry, and the impact of inflows on the current balance. 


\section{IMPORTANCE OF FDI IN FINANCING THE GLOBAL ECONOMY}

The importance of the international movement of capital in a globalized world in which freedom of economic choice is advocated has reached its full empirical confirmation in recent decades. Foreign direct investments represent the first and most important form of international movement of capital i.e. as financing investments with foreign savings. This is best illustrated by the following chart (Chart 1), which shows the movement of FDI inflows from 1970 to the present day worldwide:

Figure 1. FDI inflows in the world from 1970 to 2019 (in milion \$).

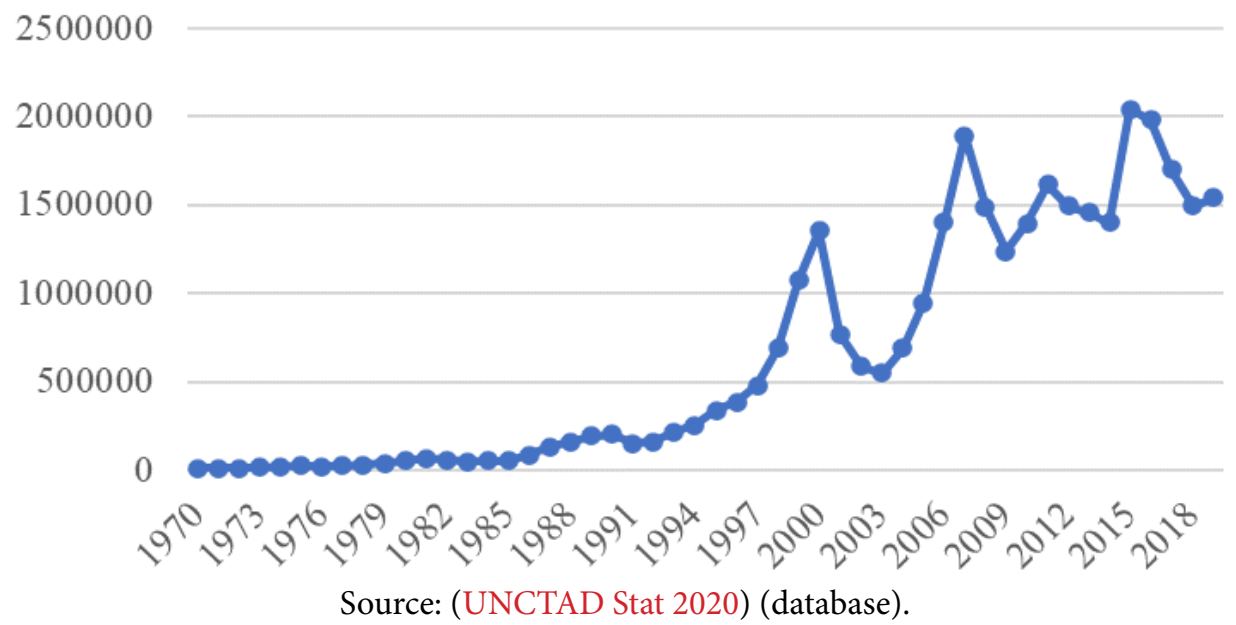

FDI inflows mostly achieved stable annual growth rates, all until the mid-1980s of the last century, as it is visible in the chart. However, the first jump in FDI inflows occurred in the second half of the 1990s, all until 2000, when they reached their certain peak, and they began to decline in the following years. Then in the middle of the first decade of the new millennium, FDI inflows again reached a dramatic jump, which peaked in 2007, and then in the next year due to the economic crises FDI inflows fell again. Since then, the movement of FDI inflows has been cyclical. FDI inflows had two major leaps, the first of which occurred in the mid-1990s, more precisely from 1994 to 2000 . In 1995, compared to 1994, the growth of FDI inflows was about \$ 90 billion, the growth in 1996 compared to 1995 was almost $\$ 50$ billion, while the absolute record in jumps was achieved in 1999, when the growth of FDI inflows was about \$ 300 billion compared to 1998. Even greater exponentially in the growth of FDI inflows occurred from 2004 all until 2007, when a new record in FDI inflows of $\$ 1.9$ trillion was reached. From this we can conclude that FDI inflows since the mid-80s are an almost regular occurrence that comes after economic crises. In the 80's, the growth of FDI inflows occurred due to the beginning of the process of globalization and the holders of those processes, the USA and Great Britain, i.e. their leaders Ronald Reagan and Margaret Thatcher, assisted by the economists of so-called Chicago school. Since then, FDI has become a global phenomenon and even in the periods not covered by the crisis, this phenomenon has shown its importance.

Regardless of the fact that one of the motives of the movement of foreign capital is the transfer of capital to countries with lower taxes, cheaper labor, cheaper other factors of production, developed countries lead in FDI inflows, but in the previous year's this ratio has decreased. This can be seen in the following chart (Chart 2): 
Figure 2. FDI inflows by groups of countries from 1970 to 2019 (in milion \$).

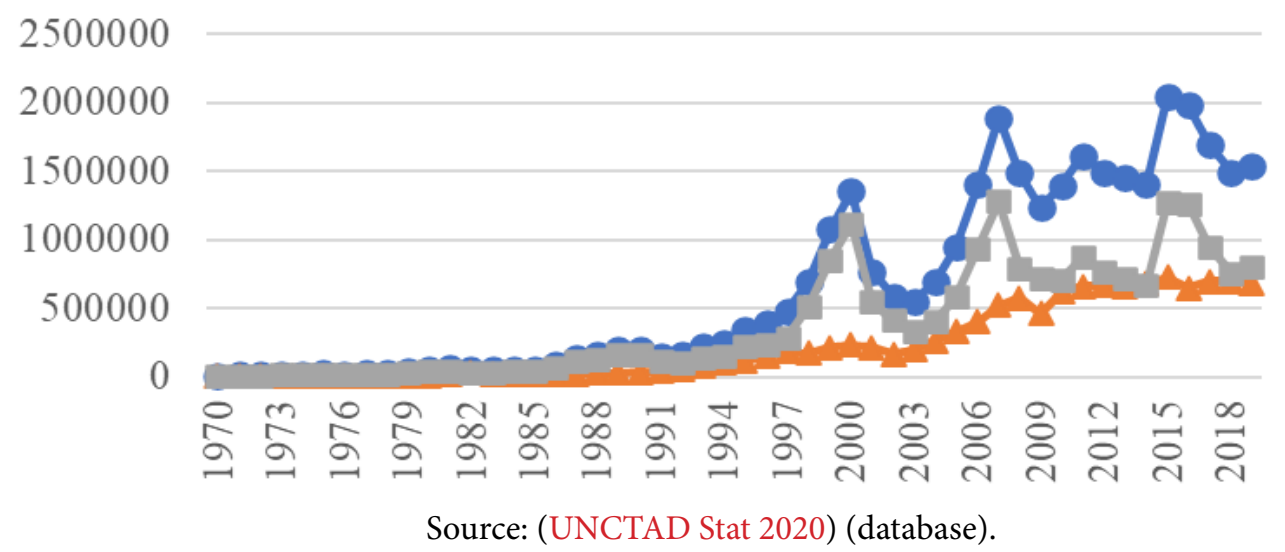

The chart shows a correlation between the decline in FDI inflows and the decline in those inflows in developed countries, while developing countries recorded a constant increase in FDI in the observed period (World - blue color; Developing countries - orange; Developed countries - grey). Developed countries are still the holder in terms of the overall level of FDI inflows in the world economy. However, there is a visible tendency for developing countries to equalize FDI inflows with developed countries.

\section{THE STATE OF THE SERBIAN ECONOMY AND FDI INFLOWS}

\subsection{BASIC MACROECONOMIC INDICATORS}

The following table (Table 1) presents the basic macroeconomic indicators for the period from 2005 to 2019, which represents a broader framework than the one in which we analyze the impact of FDI on economic growth and development.

Table 1. Basic macroeconomic indicators of Serbia from 2005 to 2019.

\begin{tabular}{cccccc}
\hline Years & GDP & $\begin{array}{c}\text { Real GDP } \\
\text { growth (in \%) }\end{array}$ & $\begin{array}{c}\text { Unemployment } \\
\text { according to the } \\
\text { survey }\end{array}$ & $\begin{array}{c}\text { Earnings (average for the } \\
\text { period, in euros) }\end{array}$ & $\begin{array}{c}\text { Public debt of the Republic } \\
\text { of Serbia (central level of the } \\
\text { state, in\% of GDP) }\end{array}$ \\
\hline 2005 & 22.276 & 5,5 & 20,8 & 210,4 & 47,6 \\
2006 & 25.906 & 4,9 & 20,9 & 257,8 & 33,9 \\
2007 & 31.551 & 6,4 & 18,1 & 347,1 & 27,9 \\
2008 & 35.701 & 5,7 & 13,6 & 402,0 & 26,8 \\
2009 & 32.486 & $-2,7$ & 16,1 & 337,8 & 30,9 \\
2010 & 31.546 & 0,7 & 19,2 & 331,8 & 39,5 \\
2011 & 35.432 & 2,0 & 23,0 & 372,5 & 42,8 \\
2012 & 33.679 & $-0,7$ & 23,9 & 366,1 & 52,9 \\
2013 & 36.427 & 2,9 & 22,1 & 388,5 & 56,0 \\
2014 & 35.467 & $-1,6$ & 19,2 & 379,8 & 66,2 \\
2015 & 35.716 & 1,8 & 17,7 & 367,9 & 70,0 \\
2016 & 36.723 & 3,3 & 15,3 & 374,5 & 67,8 \\
2017 & 39.183 & 2,0 & 13,5 & 383,9 & 57,9 \\
2018 & 42.855 & 4,4 & 12,7 & 419,7 & 53,7 \\
2019 & 45.912 & 4,2 & 10,4 & 465,9 & 52,0 \\
\hline
\end{tabular}


Observing the GDP from the previous table, we can see that the value of the GDP of the Serbian economy has doubled in the previous 14 years. Namely, the GDP in 2005 was 22,276 million euros, and at the end of 2019, the level of GDP doubled to 45,912 million euros. Serbia achieved a relatively high level of real GDP growth in the period from 2005 to 2008 . This level of GDP growth was accompanied by large privatizations and the entry of foreign capital into the Serbian economy. At that time, the large investors, such as Gazprom, Fiat, Telenor and others entered the Serbian economy, which gave a large GDP growth, i.e. investing foreign money in the observed period through the privatization process itself. After the financial crises in 2008, and the floods in 2014, they would have decreased ( $2 \%$ in 2009, $0,7 \%$ in 2012 and 1,7\% in 2014). While since 2016. the GDP growth has been visible, which in in 2018 and 2019 amounted to over 4\%. This GDP growth can be attributed to the increase in production due to the increase in foreign investments, because in this period no significant privatization of a state-owned company was recorded, and the growth of foreign investments was pronounced.

One of the benefits of FDI inflows is the impact of inflows on improving the balance of payments picture. In order to be able to see the impact of foreign investment on economic growth and development, and the overall economy of Serbia, we must consider FDI flows as well, and we must observe the balance of payments, to determine the impact that FDIs produce in the field of foreign relations. The current account of the balance of payments for the period from 2010 to 2019 is presented below: 


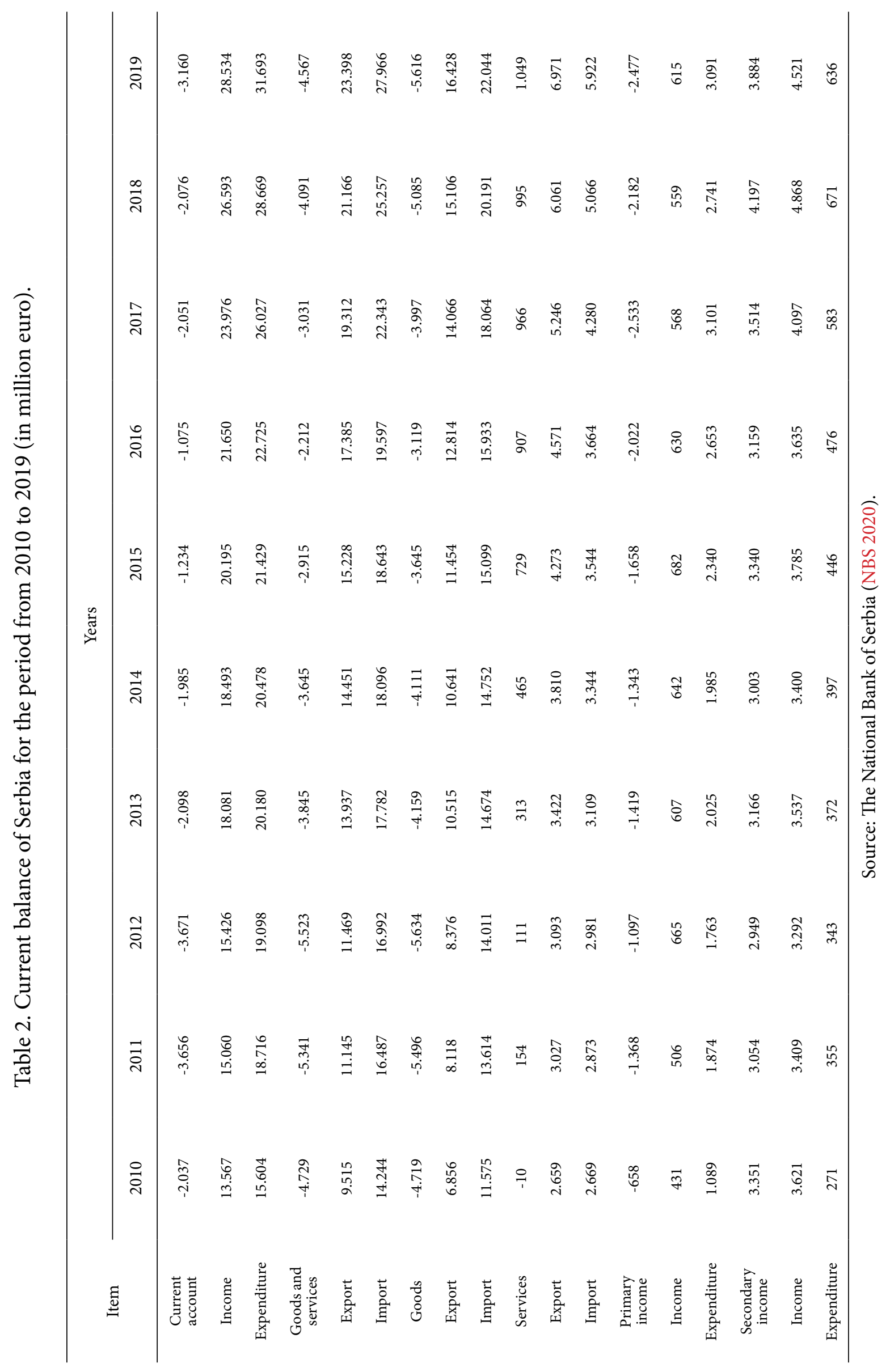


From the previous table, the current balance of Serbia over a given period of time can be seen, i.e. the movement of the surplus/deficit of the current balance cumulatively and items/cross-section of the current balance, i.e. balance of goods and services, balance of primary income, and balance of secondary income can be seen. There is a significant link between FDI inflows and a country's balance of payments, which is reflected in different current and capital balance sheet items. Firstly, by increasing FDI inflows in the country increases production, and further export of goods and services, and secondly, FDI inflows increase capital balance revenues, which is a direct consequence of FDI inflows during one year. From the previous table, you an abbreviated presentation of the current balance of Serbia for the period from 2010 to 2019 can be seen. In the observed period, the trend of the negative balance of the current balance for the given period can be noticed, but also of all items, i.e. the cross-section of the current balance. Let's take for example the year 2019, in which the current account balance amounted to -3.16 billion euro, while the balance of goods and services was in an even larger deficit, this deficit amounted to 5.567 billion euro. Negative trends are also noticeable in the field of primary income, where the net outflow of realized income on the basis of foreign investment in the Serbian economy, which in 2019 amounted to net -2.47 billion euro, can be seen in expenditure transactions. The only item that contributes to the balance of payments balance over the observed period, and which has a stable growth trend in a given period is the balance of secondary income, which includes remittances from abroad. The surplus, which amounted to 2.88 billion euro in 2019 , significantly contributes to the reduction of the deficit from foreign relations in the field of balance of goods and services and primary income.

\subsection{FDI INFLOWS IN SERBIA}

The state of Serbia bases its economic policy and economic growth plan on attracting foreign investments. Such a policy is accompanied by Government measures, primarily because foreign and domestic investors are treated equally, it is important that it is an investor who owns capital and is willing to invest. The following chart (Chart 3) shows the trends in the inflow of foreign direct investments in the Serbian economy from 2010 to 2019:

Figure 3. FDI inflows in Serbia from 2010 to 2019.

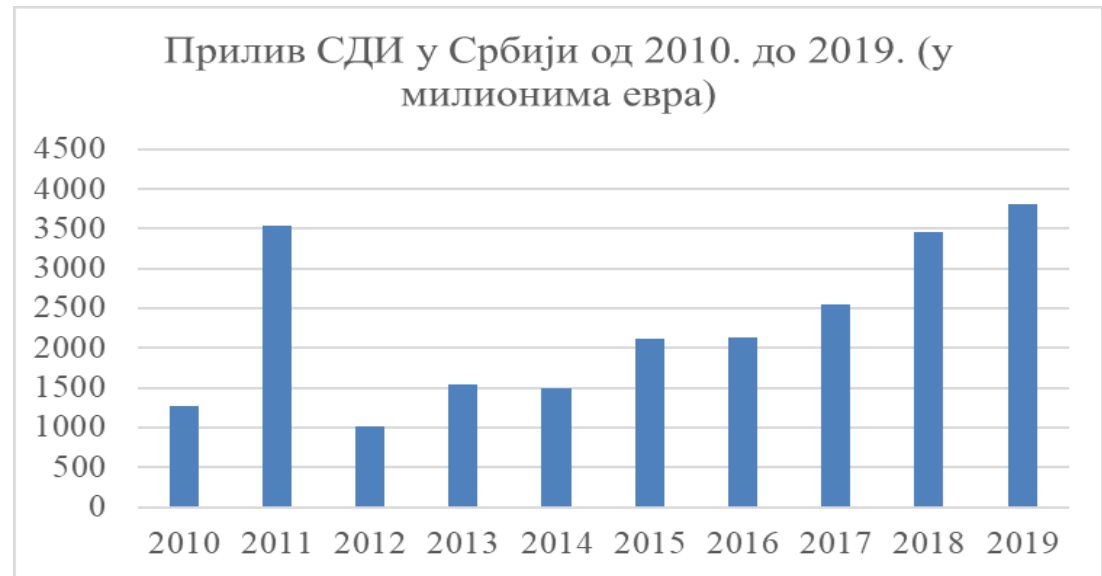

Source: The National Bank of Serbia (NBS 2020).

From the previous chart, we can see that the trend of FDI inflows from 2010 to 2019 is positive. In 2010, the inflow of FDI amounted to 1.2 billion euro, while in 2011 a dramatic jump was achieved, so the amount in this year was 3.5 billion euro. After that, in 2012, the inflow of FDI was around 1 billion euro, and from 2012 to 2019, it had a constant growth. Growth reached its maximum in 2019, when FDI inflows amounted to 3.8 billion euro, which is a record inflow of FDI in the Serbian economy. 
The largest investments, observed historically, in terms of the volume of invested capital, were directed to the privatization of public companies. All large foreign investments in the Serbian economy took place in very attractive industries, in banking, telecommunications, energy, and retail. What is characteristic for these areas is that they are not export-oriented. Foreign companies (investors) are guided by the motives of gaining high profits, which are mostly not reinvested, but exported from the domestic economy. The structure of FDI inflows in the Serbian economy is dominated by investments in the processing industry in the amount of $29.30 \%$ of the total level of FDI for a given period, which amounts to 6.7 billion euro. The next significant areas that are interesting for foreign capital are financial activities with a share of $17.17 \%$, trade with a share of $13.81 \%$, construction with a share of $11.92 \%$, then investments in mining, with a share of $7.59 \%$, and investments in transport and storage with a share of $6.86 \%$. All other activities did not attract significant investments of foreign investors in the observed period.

\section{RESEARCH METHODOLOGY}

\subsection{REGRESSION MODEL}

So far, we have observed the relations in FDI inflows with other economic indicators in the economy. Now the task is to determine the degree of agreement, i.e. regularity between these variables. "Establishing the average regular quantitative ratio of the two observed phenomena implies determining the parameters of simple linear regression" (Komić, 2000). A simple linear regression model to determine this relationship is:

$$
Y_{i}=\beta_{0}+\beta_{1} x_{i}+\varepsilon_{i}, \quad i=1,2, \ldots, N
$$

where: $Y_{i}$ are the $i$ - dependent variable; $x_{i} i$ - value of the independent variable; $\beta_{0}$ and $\beta_{1}$ are called regression parameters; $\varepsilon_{i}$ is a stochastic term or random error, and $N$ is the size of the base set. The estimated value of the simple linear regression function based on the data from the sample is:

$$
\hat{Y}_{i}=b_{0}+b_{1} x_{i}
$$

In this equation, $\hat{Y}_{i}$ denotes the value of $Y$ that is exactly on the best-adjusted regression line, and $b_{0}$ and $b_{1}$ are the estimates of the unknown regression parameters on the base set.

Based on a simple linear regression model, we can determine the regularity in the behavior of GDP as a dependent variable in relation to the behavior of the independent variable, i.e. FDI movements, all in order to determine the direction of movement of these variables and their interrelationship. The specification of a simple linear regression model is:

$$
\begin{aligned}
& \hat{Y}_{i}-\text { value of GDP (dependent variable), } \hat{Y}_{i}=\mathrm{GDP}, \\
& x_{i}-\text { inflow of FDI (independent variable), } x_{i}=\mathrm{FDI}, \\
& b_{0} \text { - parameter of dependent variable, } \\
& b_{1} \text { - parameter of independent variable. }
\end{aligned}
$$




\subsection{CORRELATION}

The correlation between the variables tells us in which direction the two variables are moving. In the case of observing only two phenomena, the coefficient of simple linear correlation is determined, the calculated value of which shows the intensity and direction of the interdependence of the observed phenomena, if in reality this connection exists. The simple correlation coefficient can be calculated in several ways, the most significant using the following formula (Komić, 2000):

$$
r=\frac{n \sum x y-\sum x \sum y}{\sqrt{n \sum x^{2}-\left(\sum x\right)^{2}} \sqrt{n \sum y^{2}-\left(\sum y\right)^{2}}}
$$

Due to the complexity of calculating the elements of the previous formula, it is easier to use the software when calculating the correlation coefficient itself.

\section{EMPIRICAL RESEARCH}

\subsection{FDI INFLOWS AND ECONOMIC GROWTH}

According to the earlier specification of a simple linear regression model, we will determine the parameters of the model in order to determine the function in which FDI inflows are an independent variable and the GDP level in a given function is a dependent variable. Through the observed period, we noticed a positive growth of the observed variables; on the following scattering diagram we can see the movement of these phenomena:

Figure 4. Scatter diagram: FDI inflow and GDP value movements 2010-2019 (in million euro).

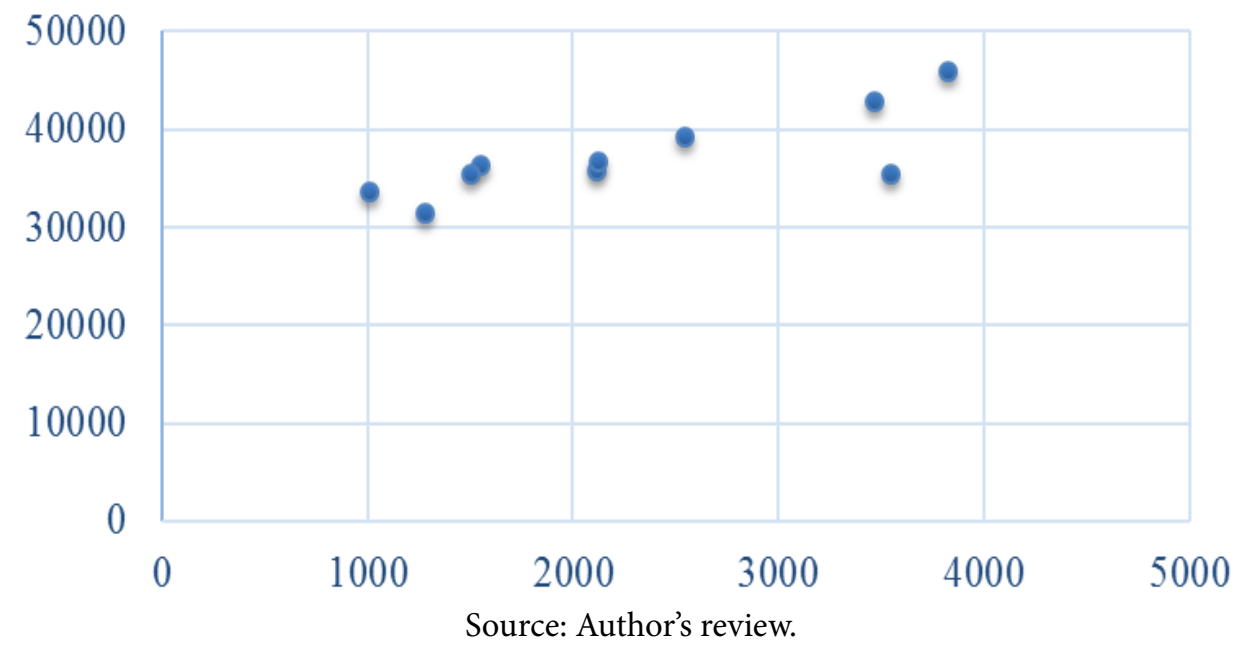

The linear growth of these two variables, FDI inflows ( $\mathrm{x}$ - on chart) and GDP ( $\mathrm{y}$ - on chart) can be seen from the previous chart. In order to make a model, i.e. determine parameters we use the statistical program SPSS. The estimated parameters are shown in the following table: 
Table 3. Estimation of regression model coefficients.

Estimation of regression model coefficients

\begin{tabular}{cccccc}
\hline & & & & \multicolumn{2}{c}{$95 \%$ Confidence interval } \\
Parameters & Value & Mean & Variance & $\begin{array}{c}\text { Lower } \\
\text { limit }\end{array}$ & Upper limit \\
GDP & 29663,989 & 29663,989 & 7000967,942 & 24379,904 & 34948,074 \\
FDI & 3,323 & 3,323 & 1,130 & 1,201 & 5,446 \\
\hline
\end{tabular}

Source: Author's calculation in the SPSS program.

Based on the previously calculated parameters, a linear model can be set up to describe the linear relationship between FDI inflows as an independent variable, and the movement of GDP values as a dependent variable:

$$
\mathrm{GDP}=29.663,989+3,323 * \mathrm{FDI}
$$

The obtained model shows that the parameter $b_{0}$ is equal to $29,663.99$, which shows the expected value of the dependent variable of GDP, if the value of SDI is equal to zero. According to the model, if there were no FDI inflows, the value of GDP would be 29 billion euro. Parameter $b_{1}$ shows the change of the dependently variable of GDP, if the independently variable of FDI increased by one unit (in this model it is one million), then the value of GDP would change by 3.3 million euro.

Table 4. Analysis of regression model variance.

\begin{tabular}{|c|c|c|c|c|c|}
\hline \multicolumn{6}{|c|}{ Analysis of regression model variance } \\
\hline $\begin{array}{l}\text { Source } \\
\text { of variation }\end{array}$ & $\begin{array}{l}\text { Sum } \\
\text { of squares }\end{array}$ & Variab. & $\begin{array}{c}\text { Mean } \\
\text { squared }\end{array}$ & $\mathrm{F}$ & Significance \\
\hline Regression & 102406582,753 & 1 & 102406582,753 & 13,038 & 0,007 \\
\hline Accidental mistake & 62836899,247 & 8 & 7854612,406 & & \\
\hline In total & 165243482,000 & 9 & & & \\
\hline
\end{tabular}

Source: Author's calculation in the SPSS program.

By analyzing the variance of the previous linear model, it can be concluded that the previous model is statistically significant based on the Fdistribution. This model is significant at the significance level $\alpha=0.05$. The value of the $F$ schedule for the given degrees of freedom is 289 , which is less than the obtained result $\mathrm{F}=13,038$.

For these two variables, FDI inflows and GDP value movements, but also for other other macroeconomic indicators, it is possible to determine the correlation value. Due to the complexity of calculating the elements of the correlation coefficient formula, it is easier to use the software when calculating the correlation coefficient itself. The following table provides a correlation matrix that shows the correlation coefficients of FDI inflows and movements of GDP, unemployment, wages, public debt and employment: 
Table 5. Correlation matrix I.

\begin{tabular}{|c|c|c|c|c|c|c|c|c|}
\hline \multicolumn{9}{|c|}{ Correlation matrix I } \\
\hline & & & $\begin{array}{c}\text { FDI } \\
\text { inflow }\end{array}$ & GDP & Unemploy. & Earnings & $\begin{array}{c}\text { Public } \\
\text { debt }\end{array}$ & $\begin{array}{l}\text { Number } \\
\text { of employ. }\end{array}$ \\
\hline \multirow{6}{*}{$\begin{array}{l}\text { FDI } \\
\text { inflow }\end{array}$} & & Coefficient & & 0,769 & $-0,571$ & 0,693 & $-0,171$ & 0,700 \\
\hline & & Mean & & 0,664 & $-0,456$ & 0,578 & $-0,126$ & 0,586 \\
\hline & & Variance & & 0,032 & 0,055 & 0,042 & 0,076 & 0,041 \\
\hline & \multirow{2}{*}{$\begin{array}{c}95 \% \\
\text { Confidence } \\
\text { interval }\end{array}$} & $\begin{array}{l}\text { Lower } \\
\text { limit }\end{array}$ & & 0,307 & $-0,855$ & 0,167 & $-0,643$ & 0,177 \\
\hline & & $\begin{array}{l}\text { Upper } \\
\text { limit }\end{array}$ & & 0,937 & 0,013 & 0,909 & 0,404 & 0,909 \\
\hline & $\mathrm{N}$ & & 10 & 10 & 10 & 10 & 10 & 10 \\
\hline
\end{tabular}

Source: Author's calculation.

According to the presented matrix, the annual inflow of FDI is positively correlated with the annual growth of gross wages in Serbia, the correlation coefficient is 0.693 , which shows the existence of a linear correlation, i.e. with the growth of FDI inflows, gross earnings grow. A high correlation coefficient is achieved between the observed variable and the increase in employment in the period from 2010 to 2019 . The correlation coefficient between these two variables is 0.7 , which shows a high correlation between FDI inflows and the increase in employment in the observed period. The correlation between FDI inflows and unemployment is inverse, because the correlation coefficient is -0.571 , which we can say is slightly above the significant inverse movement of these two variables, while the movement of FDI inflows and public debt in the observed period does not achieve a significant correlation.

\subsection{FDI INFLOWS AND CURRENT ACCOUNT BALANCE}

Considering the impact that FDI inflows have on the economy of the host country, in this case on the economy of Serbia, we continue with the analysis of the impact of FDI on some significant items of the current balance of Serbia. We perform the analysis by establishing the relationship between FDI inflows and the movement of current account items, and they are: current account balance, balance of goods and services, export of goods and services, and primary income. In the first part of the analysis, we will deal with the charts describing specific relationships between FDI and individual items of the current balance, then we will present the more precise statistical dependence between FDI inflows, on the one hand and movements of the observed balance variables, on the other hand by a correlation matrix. The following chart shows the movement of FDI (blue line) and the movement of current account deficit (red line), and balance of goods and services deficit (green line) as well: 
Figure 5. FDI inflows and current account surplus / deficit of goods and services (in million euro).

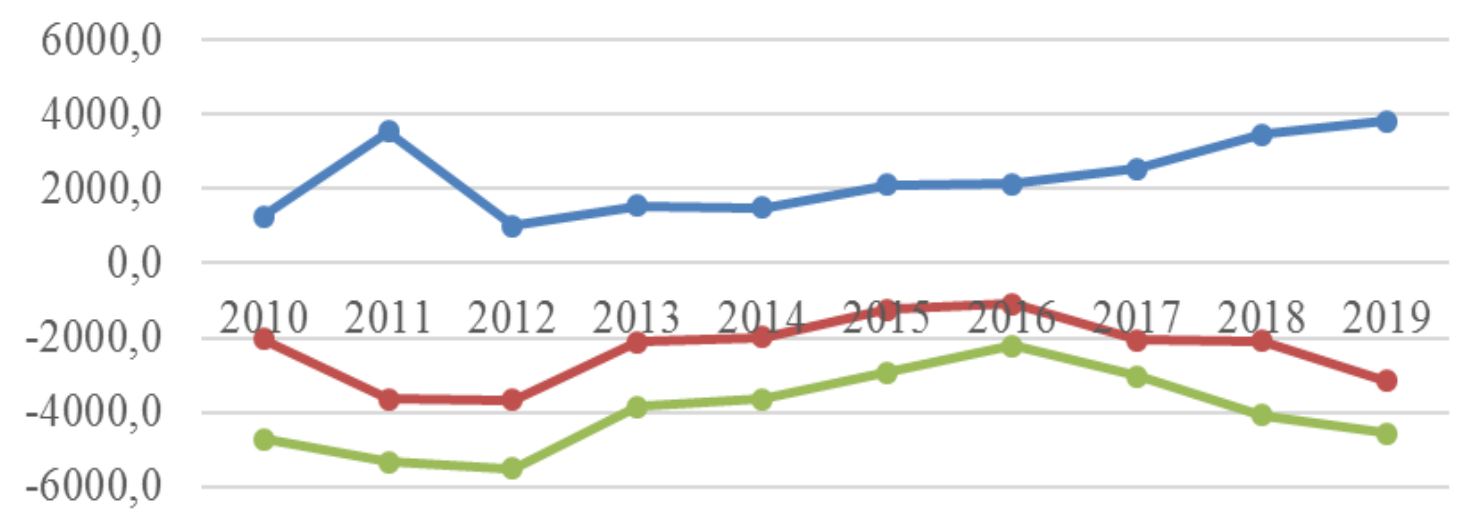

Source: The National Bank of Serbia (NBS 2020).

The analysis of data show the impact that the FDI inflows have on the two observed balance of payments items that are of high importance for each economy in the world, and those are the current balance and the balance of goods and services. Since 2010, except for 2011, when there was one major privatization, the growth of FDI inflows has had a slight growth, in 2010 the current account deficit amounted to about 2 billion euro, in the next year we follow the jump in FDI inflows and the movement of current account balance to deficit of 3.6 billion, the same level of deficit was achieved in 2012. In the period from 2013 to 2016, there are no significant jumps in terms of FDI inflows, and the current account balance and balance of goods and services are experiencing the certain stability. The current account deficit in this period was moving downwards, in 2013 the deficit was 2 billion euro, in 2014 it was 1.9 billion euro, the downward decline in the deficit also occurred in 2015, while the current account deficit in 2016 amounted to just over a billion euro. From 2017 to 2019, a significant change in the growth of FDI inflows is visible, while the observed deficits continued with an upward trend in the same period. In the following chart, we observe the ratio of FDI inflows with the growth of exports of goods and services in the period from 2010 to 2019.

Figure 6. FDI inflows and export of goods and services (in milion euro).

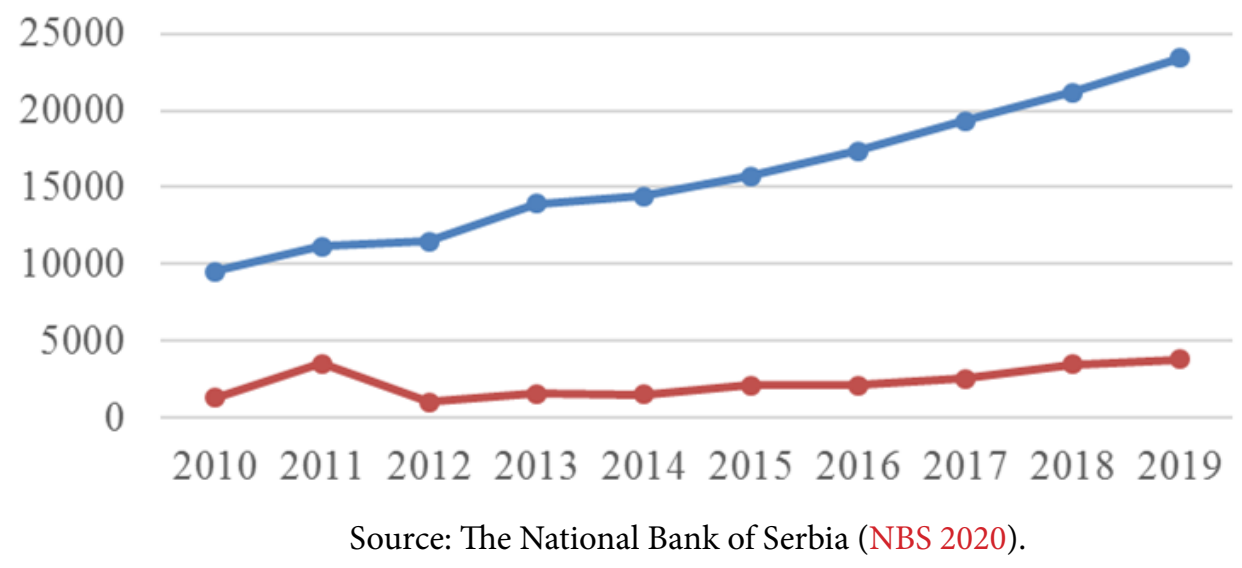

The observed period is characterized by the growth of foreign investments (red line) and growth of exports of goods and services (blue line) as well; it can be seen that there is a certain relationship between the observed phenomena, but it is noticeable that the growth of exports, represented by the above curve in the previous chart grows much faster than FDI inflows. The growth of export of goods and services had a significant trend in the period when the trend of FDI inflows had a 
stagnant character. We further deepen the analysis by analyzing the item of primary income, as further shown in the following chart:

Figure 7. FDI inflow and balance of primary income (in million euro).

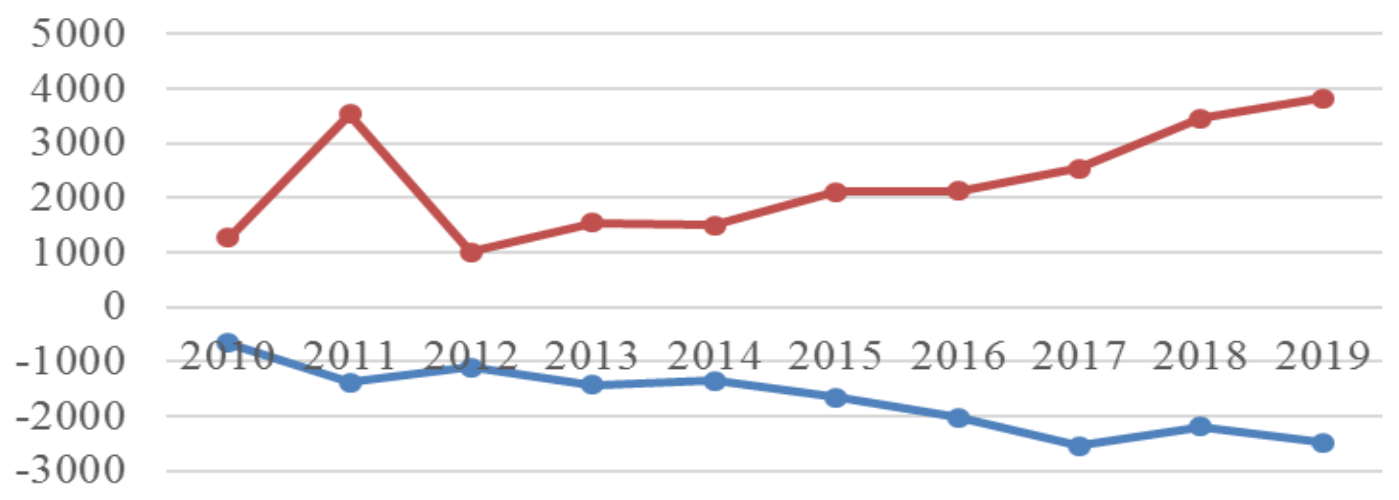

Source: The National Bank of Serbia (NBS 2020).

The movement of the two phenomena from the previous chart also shows certain regularities, which is normal to expect. With the growth of foreign direct investments (red line) in the domestic economy, the outflow of capital (blue line) in the future period on the basis of dividend payment is also growing. In order to determine the statistical significance of the influence of the observed variable (FDI inflows) on the movement of balance of payments items, we will again use the correlation matrix, which is given in the following table:

Table 6. Correlation matrix II.

\begin{tabular}{|c|c|c|c|c|c|c|c|}
\hline \multicolumn{8}{|c|}{ Correlation matrix II } \\
\hline & & & $\begin{array}{c}\text { FDI } \\
\text { inflow }\end{array}$ & $\begin{array}{l}\text { Current } \\
\text { account } \\
\text { balance }\end{array}$ & $\begin{array}{l}\text { Export } \\
\text { of goods } \\
\text { and } \\
\text { services }\end{array}$ & $\begin{array}{l}\text { Primary } \\
\text { income } \\
\text { balance }\end{array}$ & $\begin{array}{c}\text { Balance of } \\
\text { goods and } \\
\text { services } \\
\text { balance }\end{array}$ \\
\hline \multirow{6}{*}{$\begin{array}{l}\text { FDI } \\
\text { inflow }\end{array}$} & & Coefficient & & $-0,157$ & 0,631 & $-0,661$ & $-0,058$ \\
\hline & & Mean & & $-0,115$ & 0,514 & $-0,545$ & $-0,042$ \\
\hline & & Variance & & 0,076 & 0,049 & 0,046 & 0,077 \\
\hline & \multirow{2}{*}{$\begin{array}{c}95 \% \\
\text { Confidence } \\
\text { interval }\end{array}$} & $\begin{array}{l}\text { Lower } \\
\text { limit }\end{array}$ & & $-0,630$ & 0,068 & $-0,895$ & $-0,573$ \\
\hline & & $\begin{array}{l}\text { Upper } \\
\text { limit }\end{array}$ & & 0,420 & 0,881 & $-0,116$ & 0,486 \\
\hline & $\mathrm{N}$ & & 10 & 10 & 10 & 10 & 10 \\
\hline
\end{tabular}

Source: Author's calculation.

What we previously observed visually on the charts, we analyze more precisely with the correlation matrix. The correlation says that the inflow of FDI in a given period is positively correlated with the export of goods and services, we have a value of the correlation coefficient of 0.631 . Likewise, the balance of primary income is inversely related to the inflow of foreign investments, again for 
a given period. The inverse coefficient between these two variables of 0.661 was determined by correlation. The correlation matrix did not determine a significant direction of FDI inflows and the current account deficit (coefficient -0.157), and the balance of goods and services deficit (coefficient $-0.058)$ as well.

\subsection{IMPACT OF FDI INFLOWS ON THE MANUFACTURING INDUSTRY}

From the previous part of the work we could see that most FDI inflows for the period from 2010 to 2019 were the result of foreign investment in the manufacturing industry. For this reason, it is possible to analyze the impact that FDI has created precisely in the field of manufacturing production. We will observe the situation in the processing industry from the aspects of turnover in industry, employment and added value per employee, i.e.from the aspect of productivity of the processing industry. An overview of FDI, value added per employee and employment in the manufacturing industry is given in the following table:

Table 7. FDI inflows, value added per employee and employment in the manufacturing industry in the period from 2010 to 2019.

\begin{tabular}{cccc}
\hline Years & $\begin{array}{c}\text { FDI in the } \\
\text { manufacturing industry } \\
\text { (in millions of euros) }\end{array}$ & $\begin{array}{c}\text { Value added per } \\
\text { employee employed in the } \\
\text { manfacturing industry } \\
\text { (in 000 dinars) }\end{array}$ & $\begin{array}{c}\text { Employment in the manufacturing } \\
\text { industry } \\
\text { (in 000) }\end{array}$ \\
\hline 2010 & 329,4 & 1118 & 405 \\
2011 & 631,1 & 1209 & 393 \\
2012 & 521,2 & 1421 & 382 \\
2013 & 679,2 & 1430 & 378 \\
2014 & 535,2 & 1497 & 369 \\
2015 & 721,1 & 1562 & 380 \\
2016 & 749,5 & 1723 & 393 \\
2017 & 634,3 & 1839 & 417 \\
2018 & 929,5 & 1852 & 444 \\
2019 & 996,9 & & 459
\end{tabular}

Source: The National Bank of Serbia (NBS 2020) and (The Statistical Office of the Republic of Serbia. Baza podataka 2020).

As we established earlier, FDI inflows in the manufacturing industry for a given period relate to the level of $30 \%$ of the total inflow level from 2010 to 2019. The first column of the previous table shows the inflow of FDI by years, where it can be seen that the inflow of FDI in the manufacturing industry in 2019 amounted to 996.9 million euros, which is three times higher inflow than in 2010. The growth of value added per employee in this industry grew from 1.1 billion dinars in 2010, to 1.8 billion dinars in 2018, which is a growth of 1.6 times, which is relatively less than the growth of FDI inflows for a given period. Also, with the inflow of FDI, the employment in the manufacturing industry grew; for the observed period, the employment in the manufacturing industry increased by about 50,000 jobs, that is for 1,13 times. Which is in relative terms less than the growth of value 
added per employee, i.e. less growth of FDI inflows in the observed period.

In addition to the previous two variables that we observed in the manufacturing industry, we also observe the third, which is the total turnover in the manufacturing industry. Growth rates of total turnover in the manufacturing industry were calculated on the basis of base indices of turnover in industry. The development of annual growth rates of manufacturing industry turnover is given in the following chart:

Figure 8. Turnover growth in the manufacturing industry from 2013 to 2019 (in \%).

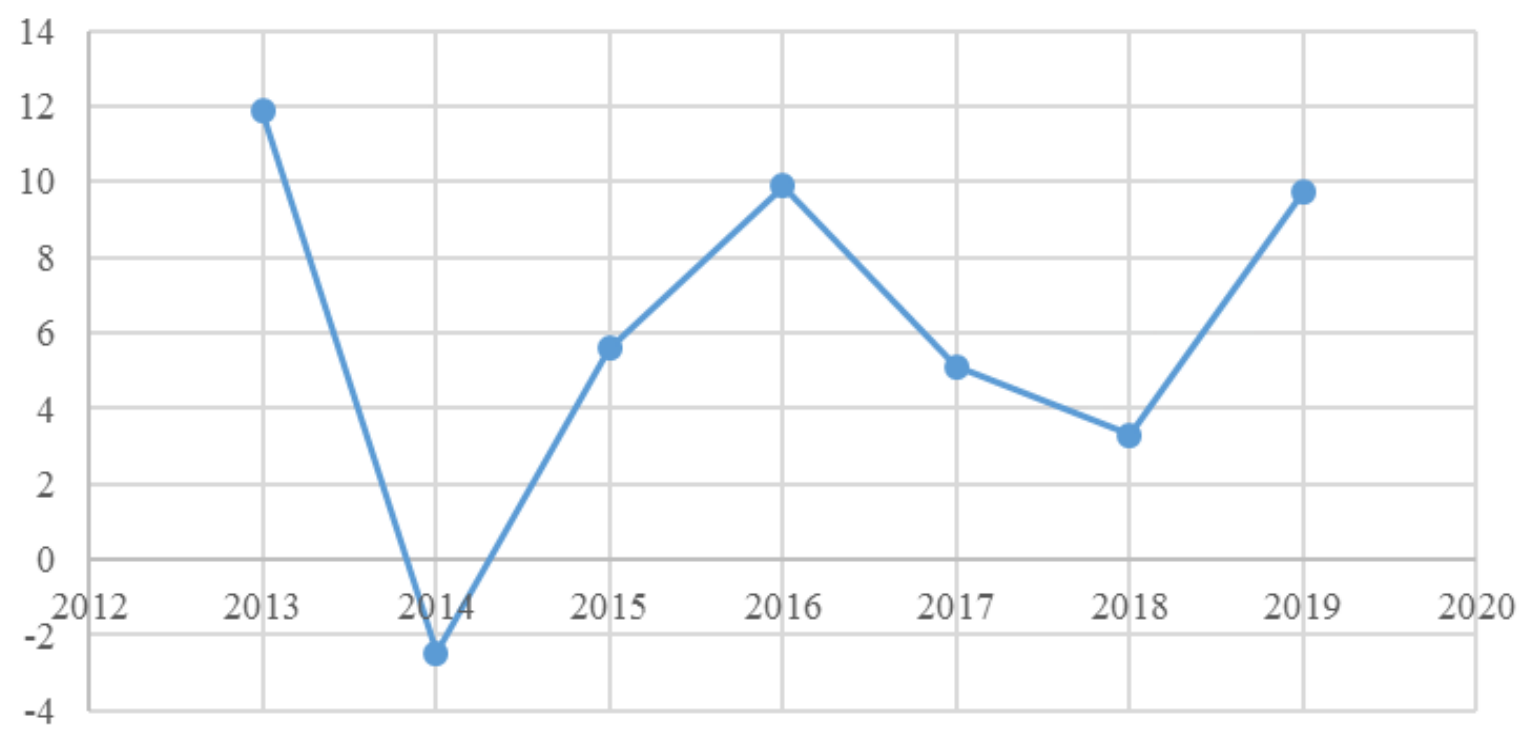

Source: Author's calculation based on The Statistical Office of the Republic of Serbia. Baza podataka (2020) data.

We will observe the relationship between FDI inflows in the manufacturing industry and previously analyzed variables related to this industry through the results of correlation coefficients:

Table 8. Correlation matrix III.

\begin{tabular}{|c|c|c|c|c|c|c|}
\hline & & & $\begin{array}{c}\text { FDI } \\
\text { manufactoring } \\
\text { industry }\end{array}$ & $\begin{array}{l}\text { Turnover in the } \\
\text { manufacturing } \\
\text { industry }\end{array}$ & $\begin{array}{c}\text { Added } \\
\text { value in the } \\
\text { manufacturing } \\
\text { industry }\end{array}$ & $\begin{array}{c}\text { Number of } \\
\text { employees } \\
\text { in the } \\
\text { manufacturing } \\
\text { industry }\end{array}$ \\
\hline \multirow{6}{*}{$\begin{array}{l}\text { FDI inflow } \\
\text { in the } \\
\text { manufactoring } \\
\text { industry }\end{array}$} & & Coefficient & & 0,379 & 0,624 & 0,628 \\
\hline & & Mean & & 0,252 & 0,457 & 0,512 \\
\hline & & Variance & & 0,095 & 0,077 & 0,050 \\
\hline & $95 \%$ & $\begin{array}{c}\text { Lower } \\
\text { limit }\end{array}$ & & $-0,344$ & $-0,092$ & 0,067 \\
\hline & interval & $\begin{array}{l}\text { Upper } \\
\text { limit }\end{array}$ & & 0,802 & 0,910 & 0,882 \\
\hline & $\mathrm{N}$ & & 10 & 7 & 7 & 10 \\
\hline
\end{tabular}


The previous correlation matrix established a linear relationship between FDI inflows in the manufacturing industry, on one hand, and the growth of value added per worker, i.e. the growth in the number of employees in the manufacturing industry, on the other hand. The correlation coefficients of the observed variables are 0.624 for the relationship between FDI and value added per worker, that is 0.628 for the relationship between FDI and employment in this industry. The relationship between the inflow of foreign direct investments and the increase in turnover in manufacturing industry is almost negligible, i.e. it is closer to zero, while the coefficient is 0.3 . With this, we statistically showed the relationship between FDI inflows and the two significant variables we observed in the manufacturing industry. 


\section{CONCLUSION}

Globalization, which has affected all aspects of human life as an individual, state institutions, the state as a whole, the economy, society, lifestyle, undoubtedly has a proven impact on the creation of economic growth and economic development. What globalization enables is the connection of subjects from all over the world in a much faster, more efficient and cheaper way, which also applies to economic subjects.

Globalization enables the international movement of capital, that capital is further on disposal to the host country in financing economic growth and development. The inflow of foreign capital is significant for both developed and less developed countries, as we have seen in this work, in addition to all the advantages that foreign capital has for developing countries, yet the holders in the inflow of foreign capital are developed countries. The inflow of foreign capital takes place through three forms, and they are foreign direct investments, which are the most dominant form of international capital movements, then portfolio investments, and foreign loan capital.

Contributions made through international capital movements have become goals of Serbia's economic policy, especially in achieving economic growth. Serbia's economic policy is based on attracting foreign capital, primarily in the form of foreign direct investments, in order to finance economic growth. As a developing country undergoing a process of transition, i.e. privatization of state capital in economy, the economic policy of Serbia since 2000 is based on attracting FDI in order to finance economic growth. As one of the goals of Serbia's economic policy was aimed at attracting a sufficient amount of foreign capital, it can be said that this goal has been achieved in the past 20 years.

What is also important when analyzing FDI in the host country, is not only the attraction of foreign capital in quantitative terms, but the structural distribution of this type of foreign investment is also important. Areas of interest to foreign capital are financial activity, manufacturing industry, wholesale and retail trade, construction. Which further says that these are activities that do not have great export potential, except for the manufacturing industry. The investments in the manufacturing industry in the amount of $29.30 \%$ of the total level of FDI for the given period, which amounts 6.7 billion euro dominate in the structure of FDI inflows in the Serbian economy. The next significant areas that are interesting for foreign capital are financial activities with a share of $17.17 \%$, then trade with a share of $13.81 \%$, and construction with a share of $11.92 \%$.Other activities did not prove to be of interest to FDI.

Even such structural distribution of FDI inflows also gave certain positive outcomes in the Serbian economy. The positive outcomes presented in the previous part of the work relate to the reduction of unemployment, GDP growth (which is expressed through a significant correlation at the level of 0.769 , which is a link), export of goods and services, growth of manufacturing industry, productivity growth per worker in manufacturing industry, increase in gross wages (correlation coefficient is 0.6). FDI inflows did not give adequate results in the field of balance of payments balancing through current account items. The correlation says that the inflow of FDI in the period from 2010 to 2019 is positively correlated with the export of goods and services, we have a correlation coefficient value of 0.631.Likewise, the balance of primary income is inversely related to the inflow of foreign investments, again for a given period. The inverse coefficient between these two variables of 0.661 was determined by correlation. The correlation matrix did not determine a significant direction of FDI inflows and the current account deficit (coefficient -0.157), and the balance of goods and services deficit (coefficient -0.058). For a given period, the effects of FDI in the manufacturing industry were also observed. The correlation coefficients of the observed variables are 0.624 for the relationship between FDI in the manufacturing industry and value added per worker, and 0.628 for the relationship between FDI and employment in this industry. The relationship between the inflow of foreign direct investments and the increase in turnover in the manufacturing industry is almost negligible, i.e. it is closer to zero, while the coefficient is 0.3 . In the end, we can conclude 
that the openness of the Serbian economy has enabled the achievement of a high level of FDI since 2000. However, FDI inflows have had their positive and negative effects on the phenomena observed in this work. FDI should attract, but at the same time build an environment that will attract such foreign direct investments, which can be better used together with domestic investments in providing the long-term run sustainable growth of the domestic economy. 


\section{REFERENCES}

Alfaro, L., Chanda, A., Kalemli-Ozcan, S., \& Sayek, S. (2004). FDI and Economic Growth: The Role ofLocal Financial Markets. Journal of International Economics, 64, 89-112. https://doi.org/10.1016/j.jwb.2003.08.001

Akbar, J.H., \& McBride, J.B. (2004). Multinational enterprise strategy, foreign direct investment and economic development: the case of the Hungarian banking industry. Journal of World Business, 39, 89-105. https://doi.org/10.1016/S0022-1996(03)00081-3

Azman-Saini,W., Siong, H.L., \& Ahmad, A.H. (2010). FDI and Economic Growth: New Evidence on the Role of Financial Markets. Economics Letters, 107, 211-213. https://doi.org/10.1016/j.econlet.2010.01.027

Bengoa, M., \& Sanchez-Robles, B. (2003). Foreign Direct Investment, Economic Freedom, and Growth: New Evidence From Latin America. European Journal of Political Economy, 19, 529-545. https://doi.org/10.1016/S0176-2680(03)00011-9 (Economic Freedom)

Blomstrom, M., Lipsey, R., \& Zejan, M. (1994). What Explains Developing Country Growth? Convergence and Productivity: Gross-National Studies and Historical Evidence. Oxford. UK: Oxford University Press.

Borensztein, E., De Gregorio, J. \& Lee, J.W. (1998). How Does Foreign Direct Investment Affect Economic Growth?. Journal of International Economics, 45, 115-135. https://doi.org/10.1016/S0022-1996(97)00033-0

Bruno, R., \& Campos, N. (2013). Re-examining the Conditional Effect of Foreign Direct Investment. IZA Discussion Paper, 7458.

Dunning, J. H. (1993). Multinational enterprises and the global economy. Wokingham, UK: AddisonWesley.

Grossman, G. M., \& Helpman, E. (1991). Innovation and Growth in the Global Economy. Cambridge. MA: MIT Press.

Havranek, T., \& Irsova, Z. (2011). Estimating Vertical Spillovers From FDI: Why Results Vary and Whatthe True Effect is. Journal of International Economics, 85(2), 234-244. https://doi.org/10.1016/j.jinteco.2011.07.004

Hayat, A. (2019). Foreign direct investments, institutional quality, and economic growth. The Journal of International Trade \& Economic Development. 28(5), 561-579. doi:10.1080/096 38199.2018.1564064. https://doi.org/10.1080/09638199.2018.1564064

Hermes, N., \& Lensink, R. (2003). Foreign direct investment, financial development and economic growth. The Journal of Development Studies, 40(1), 142-163.

Komić, J. (2000). Metodi statističke analize kroz primjere: zbirka zadataka. Banja Luka: Ekonomski fakultet.

Mikerević, D. J. (2011). Finansijski menadžment. Banja Luka: Ekonomski fakultet: Finrar.

NBS. (2020, decembar 12). Baza podataka. Retrieved from the National Bank of Serbia: https://nbs.rs/sr_RS/indeks/.

Porter, M. E. (1990). The competitive advantage of nations. London: Macmillan.

Ram, R., \& Zhang, K. H. (2002). Foreign Direct Investment and Economic Growth: Evidence from Cross-Country Data for the1990s. Economic Development and Cultural Change, 51(1), 205215. https://doi.org/10.1086/345453

Salvatore, D. (2009). Međunarodna ekonomija. Beograd: Centar za izdavačku delatnost Ekonomskog fakulteta.

The Statistical Office of the Republic of Serbia. (2020, septembar 13). Baza podataka. Retrieved from the Statistical Office of the Republic of Serbia: https://data.stat.gov.rs/?caller=SDDB

UNCTAD. (2020, septembar 12). UNCTAD Stat. Retrieved from UNCTAD: https://unctadstat.unctad.org/wds/ReportFolders/reportFolders.aspx?sCS_ChosenLang=en 
Vernon, R. (1966). International investments and interna-tional trade in the product cycle. Quarterly Journal ofEconomics, 80, 190-207.

W.N.w Azman-Saini; Ahmad Zubaidi Baharumshah and Siong Hook Law, (2010), Foreign direct investment, economic freedom and economic growth: International evidence, Economic Modelling, 27, (5), 1079-1089 